\title{
Ankara ayçiçeği ekim alanlarında sorun olan domuz pıtrağı (Xanthium strumarium L.)'nın meydana getirdiği ürün kayıpları ve ekonomik zarar eşiğinin belirlenmesi
}

\section{Mustafa Selcuk BASSARAN ${ }^{1}$}

\author{
Ahmet Tansel SERIM ${ }^{1}$
}

\author{
Ünal ASAV ${ }^{1}$
}

\begin{abstract}
Determination of the yield reductions and economic threshold caused by common cocklebur (Xanthium strumarium $L_{\text {.) }}$ in sunflower production fields in Ankara
\end{abstract}

High nutritive content, using in various industrial sectors and adaptation of various regions of sunflower (Helianthus annuus L.) have allowed of cultivation and consumption at high scale. One of the important problems of sunflower prevalently cultivated in Marmara and Central Anatolia Regions is weeds. Among the weeds, common cocklebur (Xanthium strumarium L.) is very important because it has a competitive character, and there is only one herbicide registered to control this weed. The field study was carried out to determine the economic threshold of common cocklebur in sunflower from 2013 to 2015 in Ankara. According to the three-year study values, the highest sunflower plant length $(138.33 \mathrm{~cm})$, head diameter $(14.4 \mathrm{~cm})$ and 1000 -seed weight $(85.03 \mathrm{~g})$ were obtained from the control parcels while the lowest plant length $(104.17 \mathrm{~cm})$, head diameter $(10.41 \mathrm{~cm})$ and 1000 -seed weight $(62.81 \mathrm{~g})$ were taken from the parcels consisted of 16 common cocklebur plants. The economic thresholds were calculated using the current sunflower price and the herbicide, imazamox (40 $\left.\mathrm{g} \mathrm{l}^{-1} \mathrm{SL}\right)$, price. The economic threshold in 2013, 2014 and 2015 were computed as 1.22 plant $\mathrm{m}^{-2}(\mathrm{Y}=-7.139 \mathrm{x}+142.23), 0.61$ plant $\mathrm{m}-2(\mathrm{Y}=-8.041 \mathrm{x}+145.84)$, 1.97 plant $\mathrm{m}^{-2}(\mathrm{Y}=-9.78 \mathrm{x}+140.26)$. To control common cocklebur economically in Ankara herbicide applications should be done when the intensity of common cocklebur reaches the values, 0.61-1.97 plant $\mathrm{m}^{-2}$.

Keywords: Sunflower, economic threshold, common cocklebur, Xanthium strumarium

\footnotetext{
${ }^{1}$ Zirai Mücadele Merkez Araştırma Enstitüsü Müdürlüğü, Gayret Mah. FSM Bulvarı No: 66 Yenimahalle/Ankara

Sorumlu yazar (Corresponding author) e-mail: mustafaselcuk.basaran@ tarim.gov.tr Alınış (Received): 27.01.2017, Kabul ediliş (Accepted): 18.08.2017
} 


\section{$\ddot{\mathbf{O Z Z}}$}

Ayçiçeği (Helianthus annuus L.)’ nin yüksek besin içeriği, endüstride kullanım alanları ve farklı bölgelere adapte olması geniş ölçekte üretimine ve tüketimine imkân sağlamaktadır. Ülkemizde ağırlıklı olarak Marmara ve Orta Anadolu bölgelerinde üretilen ayçiçeğinin en önemli sorunlarından biri de yabancı otlardır. Yabancı otlar içerisinde domuz pıtrağı (Xanthium strumarium L.) oldukça rekabetçi bir yabanc1 ot olması ve bu yabanc1 otu kontrol edebilecek ruhsatlı tek bir herbisit olduğu için büyük önem arz etmektedir. Ayçiçeğinde sorun olan domuz pıtrağının Ekonomik Zarar Eşiği (EZE)'nin belirlenmesi amacıyla Ankara ilinde 2013-2015 yıllarında tarla denemeleri yürütülmüştür. Üç yıllık ortalamalar dikkate alındığında ayçiçeğinde en uzun bitki boyu $138.33 \mathrm{~cm}$ ile yabancı otsuz kontrolden, en kısa bitki boyu ise $104.17 \mathrm{~cm}$ ise 16 bitki $\mathrm{m}^{-2}$ olan parsellerden; en geniş tabla çapı $14.4 \mathrm{~cm}$ ile yabancı otsuz kontrolden, en dar tabla çapı $10.41 \mathrm{~cm} 16$ bitki m$^{-2}$ olan parsellerden; 1000 dane ağırlığı en yüksek 85.03 g ile yabancı otsuz kontrolden ve en düşük $62.81 \mathrm{~g}$ ile 16 bitki $\mathrm{m}^{-2}$ olan parsellerden elde edilmiştir. Deneme sonucunda elde edilen veriler kullanılarak 2016 ayçiçeği fiyatları ve imazamox (40 $\left.\mathrm{g} \mathrm{l}^{-1} \mathrm{SL}\right)$ etkili maddeli herbisit kullanılacağı var sayılarak EZE değerleri hesaplanmıştır. Denemeler sonucunda; 2013 y1linda EZE 1.22 bitki m ${ }^{-2}$ (Y=-7.139x+142.23), 2014 y1lında EZE 0.61 bitki m ${ }^{-2}$ (Y=$8.041 \mathrm{x}+145.84), 2015$ y1lında EZE 1.97 bitki m$^{-2}(\mathrm{Y}=-9.78 \mathrm{x}+140.26)$ bulunmuştur. Ankara ilinde ayçiçeğinde domuz pıtrağının ekonomik mücadelesi için tarladaki yabancı ot yoğunluğu 0.61-1.97 adet $\mathrm{m}^{-2}$,ye ulaşıldığında herbisit ile yabanc1 ot mücadelesi yapılması gerekmektedir.

Anahtar kelimeler: Ayçiçeği, ekonomik zarar eşiği, domuz pıtrağı, Xanthium strumarium

\section{GIIRIŞ}

Ayçiçeği (Helianthus annuus L.) dünyada ve ülkemizde en önemli yăg bitkilerinden biri olup, ülkemizde çoğunlukla yağlık olarak yetiştirilir. Dünya ayçiçeği üretimi son yıllarda 23 milyon ton civarına olup, Türkiye üretimde ve ekim alanlarında ilk on ülke arasında yer almaktadır (Anonymous 2017). Ülkemizde yağlık ayçiçeği üretimi, genelde Marmara, Trakya, Ege, Doğu Anadolu ve Orta Anadolu Bölgelerinde yoğunlaşmış iken, çerezlik üretimi ise, çoğunlukla Orta ve Doğu Anadolu Bölgesinde yapılmaktadır (Anonim 2016a). Ayçiçeğinin mekanizasyona uygun bir bitki olması ve yetiştiriciliğinde fazla işgücü gerektirmemesi nedeniyle, Ankara ilinde yağlık ayçiçeği üretimi yıldan yıla artmaktadır. Ülkemizde yağlık ayçiçeği 5.202.600 da alanda ekilmekte olup, 1.637.900 ton ürün elde edilmektedir (Anonim 2016a).

Ayçiçeği; uzun, boylanabilen, güçlü kök yapısı ve geniş yapraklı olması nedeniyle yabancı otlarla rekabeti diğer ürünlere göre yüksektir. Fakat yabancı otlar gibi hızlı gelişim göstermedikleri için erken dönemde (ekiminden 1-1.5 ay sonra) yabancı otlar ile rekabet söz konusudur ve homojen bir gelişim gösteremezler. Bu dönem ayçiçeği için kritik dönemdir. Ayçiçeği ile aynı ayda çimlenme gösteren yabancı otlar hızla gelişir ve ayçiçeğini baskı altına alır. Ayçiçeğinin su, 1şık ve besin maddesinden faydalanarak, bitkinin gelişimini engelleyen ve kalitede düşüşlere neden olan yabancı otlar, erken dönemde ayçiçeğiyle birlikte çimlenme gösteren 
bitki türleri olup bunların başında ise domuz pitrağ gelmektedir (Özer ve ark. 2003). Domuz pıtrağı yapraklarının geniş olması, $15-100 \mathrm{~cm}$ boylanabilmeleri ve çimlendikten sonra hızlı bir gelişim gösterebilme yeteneklerinden dolayı ayçiçeği ile rekabet gücü çok yüksektir.

Domuz pıtrağı ayçiçeğinin erken döneminde ayçiçeği ile su, mineral madde, 1şık ve yer rekabetine giderek verim azalmasına neden olduğu gibi yabancı otun kök ve toprak üstü aksam kalıntıları ayçiçeğinde allelopatik etki gösterip gelişme geriliğine neden olmaktadır (Pacanoski et al. 2014).

Ayçiçeğinde yabancı otlarla mücadelede amaç bütün yabanc1 otların öldürülmesi değil bu yabancı otların Ekonomik Zarar Eşiği (EZE)'nin altında tutulmasıdır. Yoğun herbisit kullanımı sonucunda yabanc1 ot yoğunlukları azalmayacağ gibi dayanıklı popülasyonlar ortaya çıkabilmekte, herbisit kalıntıları su kaynaklarında kirliliğe ve münavebe bitkilerinde fitotoksisiteye neden olabilmektedir (Delen ve ark. 2015). Yabancı otlarla mücadelede EZE'nin dikkate alınması tüm bu olumsuzlukları ortadan kaldırmak için atılacak ilk adımdır.

Ekonomik zarar eşiği; ekonomik zarara sebep olabilecek en düşük popülasyon seviyesidir. Başka bir tanımla; herhangi bir etmene karşı yapılan mücadele girdilerinin mücadele sonucu elde edilen kara eşit olmasıdır. Ekonomik zarar eşiği uygulamalarının mücadelede temel alınması sonucunda, yoğun ve yanlış herbisit uygulamalarının önüne geçerek ürünün kalite ve kantitesini yükseltmek ve en önemlisi insanı ve doğayı korumak hedeflenmektedir. Ekonomik zarar eşikleri birçok faktöre bağlı olup, bunların en önemlileri yetiştirilen ürünün çeşidi, birim alandaki verimi, yabanc1 otun türü, yoğunluğu, ürünün birim fiyatı ve herbisit uygulamalarının maliyetidir (Uygur ve ark. 1999, Mennan et al. 2003).

Domuz pitrağının birçok endüstri bitkileri içerisinde ekonomik zarar eşiği değerleri hesaplanmış olmasına rağmen ayçiçeği alanlarında EZE değerlerinin belirlenmesine yönelik bir çalışmaya rastlanılmamıştır. Bu bakımdan tamamlanan çalışma ayçiçeği alanlarında domuz pıtrağının EZE değerlerinin belirlenmesi konusunda yapılan ilk çalışmalardan biri olmuştur.

Ekim öncesi veya çıkış öncesi toprağa herbisit uygulayarak yabancı otların çıkışı engellenebilmektedir. Fakat tarladaki yabancı otlar sayılamadan yani ekonomik zarar eşikleri dikkate alınmadan ekim öncesi herbist uygulamaları yapıldığı için yabanc1 ot kontrol maliyeti artmakta, bazen de yapılan herbisit uygulamasindan beklenen fayda sağlanamamaktadır. Domuz pitrağ ile mücadelede çıkış sonrası herbisitler yoğun bir şekilde kullanılmaktadır (Özer ve ark. 2003). Ülkemizde Avrupa Birliğine uyum sürecinde pek çok herbisit yasaklanmıştır. Son yıllarda domuz pıtrağına karşı imazamox terkipli herbisitler kullanılmaktadır (Anonim 2016b). Ancak bu herbisitin kullanılabilmesi için de IMI Toleranslı Clearfield ayçiçeği çeşitlerinin ekilmesi gerekmektedir.

Domuz pıtrağının ayçiçeğiyle rekabetinin yüksek olması ve verime etkisinin büyük olması nedeniyle çiftçiler öncelikle herbisitlere başvurmakta ve herbisit kullanımı 
Ankara ayçiçeği ekim alanlarında sorun olan domuz pıtrağı (Xanthium strumarium)'nın meydana getirdiği ürün kayıpları ve ekonomik zarar eşiğinin belirlenmesi

her geçen sene artmaktadır. Bu çalışmada; Ankara ilinde ayçiçeği üretim alanlarında domuz pıtrağının ekonomik açıdan zarar oluşturacağı popülasyon seviyelerinin belirlenmesi ve üreticilerin kullanımına sunulması amaçlanmıştır.

\section{MATERYAL VE METOT}

Ankara ili ayçiçeği ekim alanlarında domuz pıtrağının (Xanthium strumarium L.) ekonomik zarar eşiğinin belirlenmesi amacıyla arazi çalışmaları, ayçiçeği yetiştiriciliğinin çok yoğun yapıldığı Ankara'nın Beypazarı ilçesinde çiftçi tarlalarında 2013 yılında ve Gölbaşı ilçesinde 2014-2015 yıllarında yürütülmüştür. Deneme alanında ayçiçeği bitkisi 4-5 yapraklı devrede iken parselasyon işlemi yapılmıştır. Denemede domuz pitrağ otlar el ile alınmıştır. Deneme kurulmadan önce alandaki yabancı ot yoğunlukları belirlenmiştir. Deneme karakterindeki yabanc1 ot yoğunluğunun yeterli olmadığı parsellerde suni bulaştırma yapılarak $0,2,4,8$ ve 16 adet $\mathrm{m}^{-2}$ domuz pıtrağı olacak şekilde düzenleme yapılmıştır. Parseller $3 \times 7 \mathrm{~m}$ boyutlarında ve 5 sıra ayçiçeğinden oluşmaktadır. Parsel aralarında 50, bloklar arasında ise $100 \mathrm{~cm}$ 'lik emniyet şeridi bırakılmıştır. Parsellerde sürekli kalacak olan domuz pıtrağı bitkileri için renkli rafyalar kullanılmıştır. Parsellerdeki diğer bütün yabancı otlar 10 günde bir yapılan kontrollerde elle çekilmiştir. Böylece ilk başta oluşturulan yoğunluklar sabit tutulmuş ve domuz pitrağının farklı yoğunluklarının olduğu parseller oluşturulmuştur. Değerlendirmede kenar tesirini azaltmak için ortadaki üç sıradaki ayçiçekleri değerlendirilmiştir. Ayçiçeği hasat zamanına geldikten sonra parsellerden seçilen sıralardaki ayçiçekleri elle hasat edilerek laboratuvara getirilmiştir. Her bir yabanc1 ot yoğunluğunda verim, yabanc1 otun bulunmadığı kontrol parseliyle kıyaslanmıştır. Deneme alanlarına ait aylık sıcaklık ve yağış değerleri Çizelge 1'de verilmiştir.

Çizelge 1. Denemelerin yürütüldüğ̈ü alanların sıcaklık ve yağış değerleri

\begin{tabular}{|l|c|c|c|c|}
\hline \multirow{2}{*}{ Lokasyon } & \multicolumn{2}{|c|}{ Sıcaklık (') } & \multicolumn{2}{c|}{ Toplam Yă̆ış (mm) } \\
\cline { 2 - 5 } & Sezon & Ortalama & Sezon & Ortalama \\
\hline Beypazarı-2013 & 15.6 & 13.7 & 366.6 & 404 \\
\hline Gölbaşı-2014 & 11.0 & 10.8 & 323.0 & 330.8 \\
\hline Gölbaşı-2015 & 10.5 & 10.8 & 568.5 & 352.8 \\
\hline
\end{tabular}

Deneme tesadüf blokları deneme desenine göre 4 tekerrürlü olarak kurulmuştur. Parsellerdeki ayçiçeği hasat zamanında (ağustos sonu ve eylül ayında) verim kriterleri de değerlendirmeye alınarak hasat edilmiştir. Daha sonra domuz pıtrağının yoğunluğu ile verim arasındaki istatistiksel ilişkiler regresyon uygulanarak belirlenmiştir (Uygur ve ark. 1999). Ayçiçeği verim ve verim unsurları aşağıdaki şekilde incelenmiştir.

Bitki Boyu (cm): Her parselden örnek olarak ortadaki 3 sıradan alınan, gelişmiş 10 bitkinin boyu toprak seviyesinden, merkezi dalın sonunda bulunan çiçek tablasının altına kadar olan yükseklik "cm" olarak ölçülmüştür. 
Tabla Çapı (cm): Her parselden örnek olarak alınan, gelişmiş 10 bitkinin tablalarına ait çaplar "cm" olarak ölçülmüştür.

1000 Tohum Ağırlığı (g): Her parselden 4 adet 100 tohum sayılarak, tartılıp ortalaması alınmış ve ortalama değer 10 ile çarpılarak 1000 tohum ağırlığı "gram" olarak bulunmuştur.

Verim ( $\left.\mathbf{k g ~ d a}^{-2}\right)$ : Parsel alanına göre elde edilen tohum verimi dekara çevrilerek bulunmuştur.

\section{İstatiksel ilişkilerin hesaplanması:}

Herhangi bir yabancı ot türüne karşı yapılan mücadele masraflarının, mücadele sonucu elde edilen kâra eşit olduğu nokta olarak kabul edilen ekonomik zarar eşiği aşağıdaki şekilde formüle edilmektedir.

Herbisit Maliyeti [H.M. $\left.\left(\mathrm{TL} \mathrm{da}^{-1}\right)\right]+$ Uygulama Maliyeti [U.M. $\left.\left(\mathrm{TL} \mathrm{da} \mathrm{da}^{-1}\right)\right]=$ Ürün Kaybı \% (y) x Ayçiçeği Fiyatı [A.F. $\left(\mathrm{TL} \mathrm{kg}^{-1}\right)$ ] x Ortalama Verim [V.ort. $\left(\mathrm{kg} \mathrm{da}^{-1}\right)$ ].

\section{Ekonomik Zarar Eşiği Formülü}

$$
y=\frac{\text { (H.M.) }+(\text { U.M. })}{\text { (A.F.) } x \text { (V.ort.) }} \times 100
$$

y = Yabancı ot yoğunluğuna bağlı olarak oluşan \% ürün kaybı (Uygur ve ark. 1999).

\section{Regresyon Formülü}

$\mathrm{y}=\mathrm{X}$. Katsay $1+$ Katsay 1

$\mathrm{y}=\mathrm{m}^{2}$, de yabanc1 ot sayısına bağlı olarak \% verim kayb1

$\mathrm{x}=\mathrm{m}^{2}$ 'deki yabanc1 ot sayıs

Formül A'da elde edilen " $y$ " değeri B' deki regresyon denkleminde yerine konulup buradan " $x$ " değeri çekildiğinde elde edilen değer ekonomik zarar eşiğini vermektedir.

"y" değeri hesaplanırken, domuz pıtrağının mücadelesinde ayçiçeği alanlarında kullanılan imazamox aktif maddeli herbisit değerlendirmeye alınmış, denemenin kurulduğu yıllara ait ilaçlama maliyeti (işçilik dahil) IIl Gıda Tarım ve Hayvancılık Müdürlüğü'nden, ayçiçeği fiyatı ise ticaret borsasından alınmıştır.

\section{SONUÇLAR VE TARTIŞMA}

Araştırmanın ilk yılındaki deneme, ayçiçeği yetiştiriciliğinin yoğun olarak yapıldığı Ankara ili, Beypazarı ilçesi (Oymaağaç köyü)'nde bulunan ayçiçeği tarlasında yürütülmüştür. Ayçiçeği deneme alanında 1'i monokotiledon, 8'i dikotiledon olmak üzere 9 familyaya ait 12 adet yabancı ot türü teşhis edilmiştir 
Ankara ayçiçeği ekim alanlarında sorun olan domuz pıtrağı (Xanthium strumarium)'nın meydana getirdiği ürün kayıpları ve ekonomik zarar eşiğinin belirlenmesi

(Çizelge 2). Yapılan çalışmada $\mathrm{m}^{2}$ 'de en fazla bulunan yabancı otlar Chenopodium album, Echinophora tenuifolia, Amaranthus retroflexus, Amaranthus albus ve Salsola kali olmuştur. Araştırmanın ikinci yılında deneme Ankara ili, Gölbaşı ilçesi (Halaçlı köyü)'nde bulunan ayçiçeği tarlasında yürütülmüştür. Ayçiçeği deneme alanında 1'i monokotiledon, 8'i dikotiledon olmak üzere 9 familyaya ait 10 adet yabanc1 ot türü teşhis edilmiştir (Çizelge 4). Yapılan çalışmada $\mathrm{m}^{2}$ 'de en fazla bulunan yabancı otlar $G$. aparine, A. retroflexus, E. tenufolia, $X$. strumarium ve $H$. vulgare olmuştur. Gölbaşı'nda 2015 yılında kurulan deneme alanındaki yabancı otlar Çizelge 5'de verilmiştir. Çizelge 6 incelendiğinde parsellerinde dikotiledondan 7 familyaya ait 7 yabancı ot türü bulunmuştur. Yapılan çalışmada $\mathrm{m}^{2}$ 'de en fazla bulunan yabanc1 otlar A. maurorum, A. retroflexus, C. arvensis, X. strumarium ve G. aparine olmuştur.

Deneme kurulan alanlardaki yabancı otların endüstri bitkilerinde özellikle de ayçiçeği yetiştirilen alanlarda s1k görülen yabancı otlar olduğu görülmektedir (Çoruh ve Zengin 2009, Arslan ve Kara 1997, İyigün ve ark. 1997).

Çizelge 2. Beypazarı deneme alanında bulunan yabancı ot türleri ve yoğunlukları

\begin{tabular}{|c|c|c|c|c|}
\hline \multirow{2}{*}{ Türkçe adı } & \multirow{2}{*}{ Latince adı } & \multicolumn{3}{|c|}{ Yoğunluk (adet/m²) } \\
\hline & & 2013 & 2014 & 2015 \\
\hline K. köklü tilki kuyruğu & Amaranthus retroflexus L. & 4.25 & 1.25 & 1.75 \\
\hline Yatık horoz ibiği & Amaranthus albus L. & 3.75 & 0.50 & - \\
\hline Tarhana otu & Echinophora tenuifolia L. & 4.50 & 2.50 & 1.25 \\
\hline Loğusa otu & Aristolochia maurorum L. & 1.25 & 1.25 & 2.75 \\
\hline Domuz pitrağ 1 & Xanthium strumarium L. & 3.25 & 3.75 & 2.50 \\
\hline Sirken & Chenopodium album L. & 5.25 & 1.25 & 1 \\
\hline Tarla sarmaşı̆̆1 & Convolvulus arvensis L. & 2.25 & 4.50 & 3.25 \\
\hline Soda otu & Salsola kali L. & 3.50 & - & - \\
\hline Canavar otu & Orobanche ramosa $\mathrm{L}$. & 0.50 & - & - \\
\hline Darıcan & E. crus-galli (L.) Beauv & 0.75 & - & - \\
\hline Yabani buğday & Triticum sp. & 0,25 & - & - \\
\hline Muhabbet çiçeği & Reseda lutea $\mathrm{L}$. & 1.00 & - & - \\
\hline Yapışkan otu & Galium aparine $\mathrm{L}$. & - & 2.50 & 1.50 \\
\hline Kendigelen arpa & Hordeum vulgare L. & - & - & 3.25 \\
\hline Kan damlası & Adonis aestivalis L. & - & - & 0.75 \\
\hline
\end{tabular}

Sürekli otsuz parsellerindeki bitkilerin bitki boyu, tabla çapı, tane boyu, tane eni ve 1000 tohum ağırlığ diğer tüm uygulamalara göre daha yüksek bulunmuştur (Çizelge 3). En yüksek verim sürekli otsuz $\left(81.36 \mathrm{~kg} \mathrm{da}^{-1}\right)$ parsellerinde, en düşük verim ise $\mathrm{m}^{2}$ de 16 adet $X$. strumarium bulunan parsellerden $\left(61.82 \mathrm{~kg} \mathrm{da}^{-1}\right)$ elde edilmiştir. 
Çizelge 3. Beypazarı'nda 2013 yılında kurulan denemede farklı yoğunluklarda domuz pıtrağ1 içeren parsellerden elde edilen verim, verim unsuru ve \% ürün kaybı değerleri

\begin{tabular}{|l|c|c|c|c|c|}
\hline \multirow{2}{*}{ Verim Unsurları } & \multicolumn{5}{|c|}{ Bitki Yoğunluğu (adet $\left.\mathbf{~ m}^{-2}\right)$} \\
\cline { 2 - 6 } & $\mathbf{0}$ & $\mathbf{2}$ & $\mathbf{4}$ & $\mathbf{8}$ & $\mathbf{1 6}$ \\
\hline Bitki boyu (cm) & 138.69 & 127.95 & 113.54 & 113.84 & 110.05 \\
\hline Tabla çapı (cm) & 15.41 & 12.37 & 11.46 & 10.28 & 10.69 \\
\hline $\mathbf{1 0 0 0}$ tohum ağırlığı (g) & 14.17 & 10.64 & 8.96 & 6.74 & 5.27 \\
\hline Verim (kg/da) & 81.36 & 75.28 & 72.15 & 67.39 & 61.82 \\
\hline Ürün kaybı (\%) & - & 7.47 & 11.33 & 17.17 & 24.02 \\
\hline
\end{tabular}

Ekonomik zarar eşiği araştırmalarında domuz pıtrağı yoğunlukları ile verim arasındaki ilişkinin belirlenmesinde doğrusal model kullanılmıştır ve EZE değeri 1.22 bitki $\mathrm{m}^{-2}$ olarak hesaplanmıştır (Şekil 1).

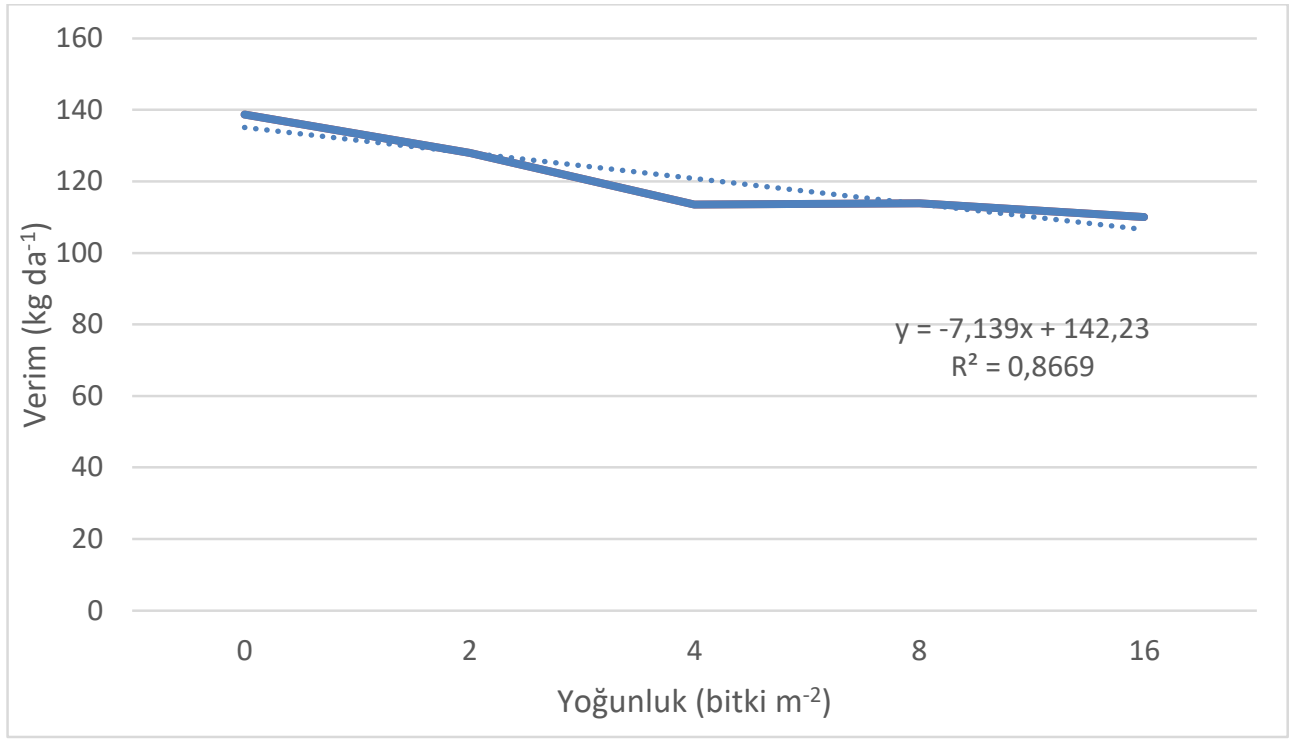

Şekil 1. Beypazarı'nda 2013 yılında kurulan denemede domuz pıtrağı yoğunlukları ile verim arasındaki ilişki

Deneme alanındaki ayçiçeği bitkileri 17.09.2014 tarihinde hasat edilmiş ve laboratuvara getirilmiştir. $X$. strumarium sayılarının ayçiçeği verim ve verim unsurlarına etkisi hesaplanmıştır (Çizelge 4). En yüksek verim sürekli otsuz $\left(134.78 \mathrm{~kg} \mathrm{da}^{-1}\right)$ parsellerinde, en düşük verim ise $\mathrm{m}^{2}$ 'de 16 adet $X$. strumarium bulunan parsellerden $\left(51.77 \mathrm{~kg} \mathrm{da}^{-1}\right)$ elde edilmiştir. 
Ankara ayçiçeği ekim alanlarında sorun olan domuz pıtrağı (Xanthium strumarium)'nın meydana getirdiği ürün kayıpları ve ekonomik zarar eşiğinin belirlenmesi

Çizelge 4. Gölbaşı'nda 2014 yılında kurulan denemede farklı yoğunluklarda domuz pıtrağı içeren parsellerden elde edilen verim, verim unsuru ve \% ürün kaybı değerleri

\begin{tabular}{|l|c|c|c|c|c|}
\hline \multirow{2}{*}{ Verim Unsurları } & \multicolumn{5}{|c|}{ Bitki Yoğunluğu $\left(\mathbf{a d e t ~}^{-\mathbf{2}}\right)$} \\
\cline { 2 - 6 } & $\mathbf{0}$ & $\mathbf{2}$ & $\mathbf{4}$ & $\mathbf{8}$ & $\mathbf{1 6}$ \\
\hline Bitki boyu (cm) & 143.2 & 127.95 & 113.54 & 113.84 & 110.05 \\
\hline Tabla çapı (cm) & 14.6 & 14.33 & 13.86 & 12.94 & 11.55 \\
\hline $\mathbf{1 0 0 0}$ tohum ağırlığı (g) & 121.72 & 113.04 & 109.86 & 97.49 & 92.25 \\
\hline Verim (kg/da) & 134.78 & 120.37 & 108.41 & 79.13 & 51.77 \\
\hline Ürün kaybı (\%) & - & 10.69 & 19.57 & 41.29 & 61.59 \\
\hline
\end{tabular}

Gölbaşında 2014 yılında kurulan denemede EZE doğrusal model kullanılarak hesaplanmış ve EZE değeri 0.61 bitki $\mathrm{m}^{-2}$ olarak bulunmuştur (Şekil 2).

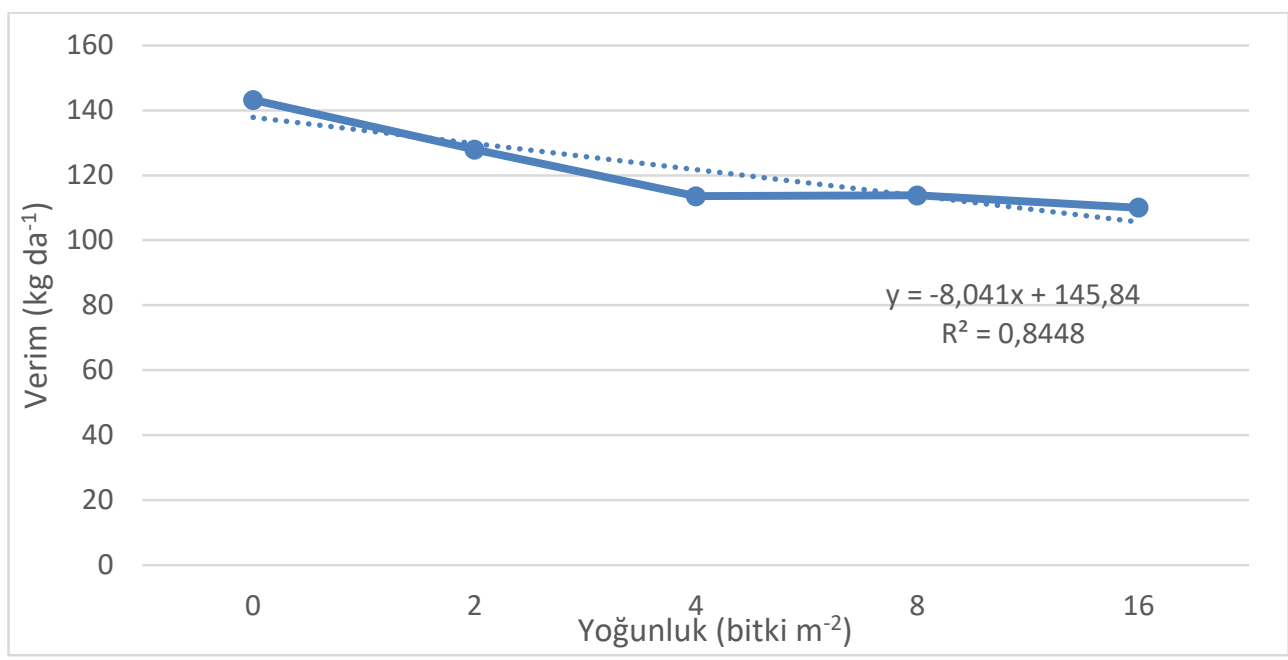

Şekil 2. Gölbaşı'nda 2014 yılında kurulan denemede domuz pıtrağı yoğunlukları ile verim arasındaki ilişki

Deneme alanındaki ayçiçeği bitkileri 31.10.2015 tarihinde hasat edilmiş ve laboratuvara getirilmiştir. Farklı domuz pıtrağı sayılarının ayçiçeği verim ve verim unsurlarına etkisi Çizelge 5'de verilmiştir.

Çizelge 5. Gölbaşı'nda 2015 yılında kurulan denemede farklı yoğunluklarda domuz pıtrağı içeren parsellerden elde edilen verim, verim unsuru ve \% ürün kaybı değerleri

\begin{tabular}{|l|c|c|c|c|c|}
\hline \multirow{2}{*}{ Verim Unsurları } & \multicolumn{5}{|c|}{ Bitki Yoğunluğu $\left(\mathbf{a d e t ~}^{-2}\right)$} \\
\cline { 2 - 6 } & $\mathbf{0}$ & $\mathbf{2}$ & $\mathbf{4}$ & $\mathbf{8}$ & $\mathbf{1 6}$ \\
\hline Bitki boyu (cm) & 133.1 & 117.7 & 110.1 & 101.3 & 92.4 \\
\hline Tabla çapı (cm) & 13.2 & 12.7 & 12.6 & 10.8 & 9 \\
\hline $\mathbf{1 0 0 0}$ tohum ağırlı̆̆ı (g) & 119.2 & 109.6 & 109.3 & 94.5 & 90.9 \\
\hline Verim (kg/da) & 119.95 & 108.95 & 100.77 & 74.7 & 50.06 \\
\hline Ürün kaybı (\%) & - & 9.18 & 16 & 37.73 & 58.27 \\
\hline
\end{tabular}


Gölbaşında 2015 yılında kurulan denemede de EZE doğrusal model kullanılarak hesaplanmış ve EZE değeri 1.97 bitki m² ${ }^{-2}$ olarak bulunmuştur (Şekil 3).

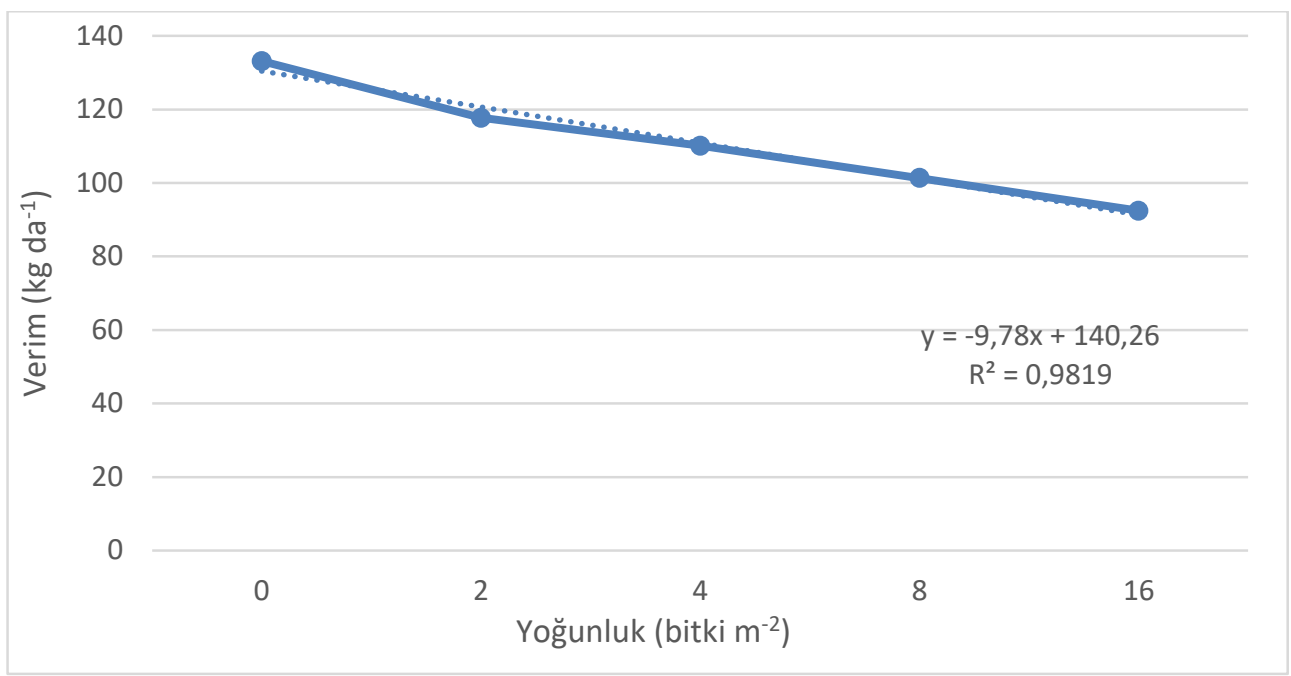

Şekil 3. Gölbaşı'nda 2015 yılında kurulan denemede domuz pıtrağı yoğunlukları ile verim arasındaki ilişki

Bu bitkide bir veya iki toprak işleme suretiyle yapılacak yabancı ot kontrol işlemi ile dikimden sonraki 4 haftalık sürede ayçiçeğinin yabancı otsuz tutulmasıyla verim artır1labilmektedir (Johnson 1971). Herbisitler ile yapılan yabanc1 ot kontrolünde kullanılan herbisitler ve bu herbisitlerin kendi içlerinde veya diğer yöntemlerle kombinasyonu verim değerlerine farklı oranlarda yansır. Herbisit (RP $17623+$ linuron) ile yabancı ot kontrolü yapıldığında \%16.5 verim artışı sağlanırken herbisit uygulaması (RP 17623 ) ile toprak işlemenin kombine edilmesi durumunda sağlanan verim artışı \%32'yi bulmaktadır (Johnson 1972). Yabancı ot kontrolü için yapilan florochloridone $\left(1.0 \mathrm{~kg} \mathrm{ha}^{-1}\right)$ uygulamas1 $\% 146$, pendimethalin $\left(1.0 \mathrm{~kg} \mathrm{ha}^{-1}\right)$ uygulamas $\% 153$ fluchloralin $(0.5 \mathrm{~kg})+$ pendimethalin $\left(0.5 \mathrm{~kg} \mathrm{ha}^{-1}\right)$ uygulamas1 $\% 88$, fluchloralin $\left(0.5 \mathrm{~kg} \mathrm{ha}^{-1}\right)+$ pendimethalin $\left(0.5 \mathrm{~kg} \mathrm{ha}^{-1}\right)+$ elle yabanc1 ot alım $\% 113$, iki kez elle ot alımı \%162 verim artı̧̧ sağlayabilmektedir (Sumathi et al. 2010).

Mısırda yapılan çalışmalarda domuz pıtrağının ekonomik zarar eşiğinin birçok alanda 1 bitki $\mathrm{m}^{-2}$ 'den düşük olduğu hesaplanmıştır (Hussain et al. 2014, Vazin et al. 2008).

Ayçiçeği alanlarında değişik gelişme döneminde yabancı otların yoğunluğunun dağılımı, verime etkileri ve mücadelesi konusunda Sırbistan'da yürütülen bir çalışmada; domuz pıtrağı ayçiçeğinin erken gelişme döneminde (V1) ayçiçeği alanlarındaki diğer yabancı otlarla karşılaştırıldığında daha baskın durumda bulunmuș, ilerleyen fenolojik dönemlerde de en baskın yabancı otlar arasında yer almıştır (Simic et al. 2011). Erken dönemde ayçiçeği alanlarındaki yabancı ot 
Ankara ayçiçeği ekim alanlarında sorun olan domuz pıtrağı (Xanthium strumarium)'nın meydana getirdiği ürün kayıpları ve ekonomik zarar eşiğinin belirlenmesi

yoğunluğunun fazla olması ürün ve kalite kayıplarına neden olmaktadır.

Beypazarı'nda kurulan denemede $\mathrm{m}^{-2}$, de 2 domuz pitrağ 1 bitkisinin bulunmasının verim kaybına etkisi \%7.47 iken 4 bitkide \%11.33, 8 bitkide 17.17 ve 16 bitkide $\% 24.02$ bulunmuştur. Her bir domuz pitrağı bitkisi düşük yoğunlukta \%3.74 verim kaybına neden olurken yüksek yoğunlukta verim kayb1 \%1.5'a düşmüştür. Domuz pıtrağ1 bitkilerinin yoğunluğu arttıkça kendi aralarında rekabete girmeye başlamaktadırlar (tür içi rekabet). Hussain et al. (2014)'ın mısırda domuz pıtrağının EZE'ni belirlemek için yaptıkları çalışmada bulgularımıza benzer sonuçlar elde edilmiştir.

Gölbaşı'nda 2014 yılında domuz pıtrağından kaynaklanan verim kaybı yoğunluk artı̧̧ına bağlı olarak \%10.69-61.59, 2015 y1lında ise \%9.18-58.27 arasında değişmiştir. Yabancı ot başına verim kaybı yoğunluk artışına bağlı olarak 2014 y1lında \%5.4-3.8 iken 2015 yılında \%4.6-3.6 olmuştur. Beypazarı'nda elde edilen verilerde olduğu gibi yoğunluk arttıkça her bir yabancı otun oluşturduğu verim kaybı düşmektedir. Beypazarı'ndan elde edilen veriler ile kıyaslandığında yabancı otlardan kaynaklanan verim kayıpları Gölbaşı'nda daha yüksektir. Bu durum alanların ekolojik yapısından ve meteorolojik farklardan kaynaklanmaktadır. EZE değerleri bölgelere, yıllara ve çalışlan bitkiye göre değişiklik göstermektedir (Başaran ve Kadığlu 2016). Yapılan bu çalışmada da bölgeler arasında da ciddi farklar görülmektedir.

Erol (2010), Tekirdağ'da 2008 yılında farklı domuz pitrağı yoğunluklarının ayçiçeği verim ve verim öğelerine etkilerini belirlemek için yürütmüş olduğu çalışmada; $21 \mathrm{~m}^{2}$ lik parsellerde 0-20-30-40-50-60 yabanc1 ot parsel $^{-1}$ yoğunluklarının ayçiçeğinde verim ve verim öğelerine etkilerini incelemiştir. Deneme yapılan alanda yabancı ot yoğunluğunun artışına bağlı olarak verim ve verim öğelerinde azalma olduğunu belirlemiştir. Parselde 60 domuz pitrağı olduğunda verimde $\% 42$ kayıp, bin dane ağırlığında ise $\% 22$ düşüş olduğu bildirilmiştir. Deneme yürütülen alanda parselde ortalama 2 bitki $\mathrm{m}^{-2}$ domuz pitrağ1 olduğunda verim kaybı \%20 civarında bulunmuştur. Ankara'da yürütülen denemelerimizde ise aynı domuz pıtrağı yoğunluğu 2013 yılında \%7.47, 2014 y1lında \%10.69 ve 2015 yılında \%9.18 verim kaybına neden olmuştur. Tekirdağ' da ayçiçeği yetiştirilen dönemdeki yağış Ankara'dan daha yüksek olduğu için verim daha yüksek olmakta ve yabancı otların da verim üzerinde oluşturduğu negatif etki daha yüksek olmaktadır. Tekirdağ'da deneme alanında yabancı otsuz parsellerin ortalama ayçiçeği tohum verimi $430 \mathrm{~kg} \mathrm{da}^{-1}$ bulunmuştur. Ankara'da ise yabanc1 otsuz parsellerdeki verim 2013-2015 y1llarında sirasıyla 81,138 ve $119 \mathrm{~kg} \mathrm{da}^{-1}$ bulunmuştur.

Gölbaşı'nda 2014 ve 2015 yıllarında yapılan denemelerden elde edilen EZE değerleri sırasıyla 0.61 ile 1.97 bitki m${ }^{-2}$ olarak hesaplanmıştır. Aynı alanda art arda yıllarda hesaplanan EZE değerleri arasındaki fark oldukça yüksektir. Bu farkın iklim koşullarından kaynaklandığı değerlendirilmektedir. Sartorato et al. (1996) soyada domuz pıtrağının EZE'nin belirlenmesi için İtalya'da yaptıkları araştırmada 
EZE değerlerini 0.12 ile 0.05 bitki $\mathrm{m}^{-2}$ bulmuşlardır. Bu denemede yağışın fazla olduğu yılda EZE değer 0.12 bitki $\mathrm{m}^{-2}$ hesaplanmıştır. Gölbaşı deneme alanında 2015 yılında 2014'den $245 \mathrm{~mm}$ daha fazla yağış görülmüştür. Yağış miktarındaki söz konusu artış EZE değerlerindeki yükselişe neden olmuştur. Sartorato et al. (1996)'nın sonuçları denememizin sonuçlarına paralellik göstermektedir.

EZE değerleri ise 2013 yılında Beypazarı'nda 1.22 bitki m² 2014 yılında Gölbaşı'nda 0.61 bitki $\mathrm{m}^{-2}$ ve 2015 yılında Gölbaşı'nda 1.97 bitki m ${ }^{-2}$ olarak hesaplanmıştır. Ankara'nın ilçelerinden hesaplanan EZE değerleri, çiftçilerin tarlalarında domuz pıtrağının çıkış sonrası herbisitler ile ekonomik kontrolü için karar verme sürecinde önemlidir. Bu değerlerin altında yabanc1 ot yoğunluğu olan alanlarda domuz pıtrağının kontrolü için herbisit kullanımına gerek olmadığını içeren bilgiler çiftçilere aktarılarak gereksiz herbisit kullanımı azaltılabilecektir.

Ayçiçeği üretim alanlarında domuz pitrağ 1 dışında yabani hardal gibi önemli yabancı otların da EZE değerlerinin belirlenmesine yönelik çalışmaların yapılması gereklidir. Bu çalışmaların her üretim bölgesi için ayrı ayrı hesaplanması da oldukça önemlidir. EZE değerlerinin yabancı ot mücadelesinde kullanımıyla birlikte diğer yabancı otlar da dikkate alınarak kritik periyot sürelerinin belirlenmesi, herbisitlerin daha ekonomik ve sürdürülebilir kullanımını ve yabancı ot mücadelesinin tarımsal çevre üzerindeki etkisinin en aza indirilmesi için önemlidir.

\section{KAYNAKÇA}

Anonymous 2017. Sunflower statistics. http://www.sunflowernsa.com/stats/world-supply/ (Erişim Tarihi: 06.02.2017).

Anonim 2016a. Tarımsal istatistikler. www.tuik.gov.tr/ (Erişim Tarihi: 20.12.2016).

Anonim 2016b. Bitki Koruma Ürünleri. Gida ve Kontrol Genel Müdürlüğü. https://bku.tarim.gov.tr/ (Erişim Tarihi: 20.12.2016).

Arslan İ. ve Kara A. 1997. Tekirdağ ili ayçiçeği ekim alanlarında saptanan önemli yabancı ot türleri rastlanma sıklıkları ve yoğunlukları. Türkiye 2. Herboloji Kongresi, Ege Üniversitesi Basımevi, Bornova-İzmir. 3-11.

Başaran B. ve Kadığlu İ. 2016. Tokat ili buğday ekim alanlarında sorun olan yabani hardal (Sinapis arvensis L.)'in ekonomik zarar eşiğinin belirlenmesi. Turkish Journal of Weed Science, 19 (1): 1-5.

Çoruh İ. ve Zengin H. 2009. Ayçiçeği (Helianthus annuus L.)'nde yabancı ot kontrolü için kritik periyodun belirlenmesi. Türkiye III. Bitki Koruma Kongresi, 15-18 Temmuz 2009, Van.

Delen N., Tiryaki O., Türkseven S. ve Temur C. 2015. Türkiye'de pestisit kullanımı, kalıntı ve dayanıklılık sorunları, çözüm önerileri. Türkiye Ziraat Mühendisliği VIII. Teknik Kongresi Bildiriler Kitab1 2. Cilt, 758-778s., 12-16 Ocak 2015, Ankara. 
Ankara ayçiçeği ekim alanlarında sorun olan domuz pıtrağı (Xanthium strumarium)'nın meydana getirdiği ürün kayıpları ve ekonomik zarar eşiğinin belirlenmesi

Erol E.H. 2010. Farklı domuz pıtrağı (Xanthium strumarium L.) yoğunluklarının ayçiçeği verimi ve verim unsurları üzerine etkileri. Yayınlanmamış yüksek lisans tezi. Namık Kemal Üniversitesi Fen Bilimleri Enstitüsü. 45 s.

Hussain Z., Marwat K.B., Cardina J. and Khan I.A. 2014. Xanthium strumarium L. impact on corn yield and yield components. Turkish Journal of Agriculture and Forestry, 38: 39-46.

İyigün Ö., Özer Z., Kutluk N. D. ve Konuşuk H. 1997. Kazova'da (Tokat) yabanc1 ot rekabetinin ayçiçeği verimine etkileri üzerine araştırmalar. Türkiye 2. Herboloji Kongresi, Ege Üniversitesi Basımevi, Bornova-İzmir. 173-180.

Johnson B.J. 1971. Effect of weed competition on sunflower. Weed Science, 19 (2): 378 380.

Johnson B.J. 1972. Weed control systems for sunflowers. Weed Science, 20 (3): 261-264.

Mennan H., Bozoğlu M. and Işık D. 2003. Economic thresholds of Avena spp. and Alopecurus myosuroides in winter wheat fields. Pakistan Journal of Botany, 35 (2):147-154.

Özer Z., Önen H., Tursun N. ve Uygur F.N. 2003. Herboloji (Yabanc1 Ot Bilimi) Cilt.1. Gaziosmanpaşa Üniversitesi Ziraat Fakültesi Yayınları. No:20 Ser. No: 10, Tokat.

Pacanoski Z., Velkoska V., Štefan T.Ý.R. and Vereš T. 2014. Allelopathic potential of Jimsonweed (Datura stramonium L.) on the early growth of maize (Zea mays L.) and sunflower (Helianthus annuus L.). Journal of Central European Agriculture, 15 (3): 198-208.

Sartorato I., Berti A. and Zanin G. 1996. Estimation of economic thresholds for weed control in soybean (Glycine max (L.) Merr.). Crop Protection, 15:63-68.

Simić M., Dragičević V, Knežević S., Radosavljević M., Dolijanović Ž. and Filipović M. 2011. Effects of applied herbicides on crop productivity and on weed infestation in different growth stages of sunflower (Helianthus annuus L.). Helia, 34 (54): 27-38.

Sumathi V., Subramanyam D., Koteswara Rao D.S. and Reddy D.S. 2010. Effect of planting pattern and weed management on weed flora and yield of rabi sunflower. Indian Journal of Weed Science, 42 (3-4): 212-216.

Uygur F.N., Kadığlu İ., Boz Ö. ve Mennan H. 1999. Yabancı otların ekonomik zarar eşiği ve Dünya ile Türkiye' deki uygulamaları. Workshop-Bit. Kor. Eko. Zarar Eşiği Model. ve Uyg., Samsun, 170-225.

Vazin F., Mahallati N., Noormohammadi G.H. and Hassanzadeh M. 2008. Common cocklebur (Xanthium strumarium) competition and economic thresholds in corn (Zea mays L.). Journal of Agricultural Sciences, 13 (3): 745-753. 